\title{
ÖNREFLEXIÓ ÉS SZÁMVETÉS JUHÁSZ ERZSÉBET PRÓZÁJÁBAN**
}

Juhász Erzsébet a huszadik század kilencvenes éveiben három kötetet bocsátott ki: esszéinek gyüjteménye, az Esti följegyzések 1993-ban, tanulmánykötete, a Tükörképek labirintusa 1997-ben, az Úttalan utaim címü esszégyüjteménye pedig 1998-ban látott napvilágot. Pályáját töredékben maradt prózai alkotása, a 2001-ben megjelent Határregény zárja. Esszéiben az alkotó ember szemszögéből veszi szemügyre a balkáni háborúkkal előállt helyzetet, a nemzeti kisebbségként való létezés állapotát, a közép-európaiság kérdését, és a remény esélyeit kutatja. Tükörképek labirintusa címü tanulmány-gyüjteményében a Monarchia irodalmát értelmezi. A Határregény cselekménye, a balkán háborúk jelenében és az Osztrák-Magyar Monarchia felbomlására következő időszakban játszódik, az elbeszélés az Osztrák-Magyar Monarchia és Nagyjugoszlávia felbomlását állítja egymással párhuzamba. A regény értelmezői figyelmeztettek arra, hogy a Határregény megközelítésekor a Juhász Erzsébet tanulmányaiban és esszéiben megfogalmazott állításokat is érdemes volna figyelembe venni. A dolgozat azt vizsgálja, hogy a Juhász Erzsébet értekező prózájának felismerései hogyan épülnek be a Határregény epikai szerkezetébe.

Kulcsszavak: identitáskérdések, balkáni háborúk, Közép-Európa, kisebbségi lét, tapasztalat.

Az utolsó tizenöt év Juhász Erzsébet számára az intenzív felkészülés ideje volt. A tanulmányok eredménye négy kötet. Esti följegyzések címü esszéi 1993-ban, tanulmány-gyüjteménye, a Tükörképek labirintusa 1997-ben, értekező próza-kötete, az Úttalan utaim 1998-ban, töredékben maradt regénye (Határregény) 2001-ben, posthumus jelent meg. A regény értelmezői hívták fel a figyelmet a Határregény és Juhász Erzsébet esszéinek kapcsolatára. Faragó Kornélia szerint a Határregényben ,az 'itt'-ség és a 'most'-ság horizontjába vont gondolatkörök, az aktualizáló olvasati lehetőségek" szükségessé teszik azt, hogy az Úttalan utaim reflexióit is

\footnotetext{
*csilla.utasi@ff.uns.ac.rs ; julijana.ispanovic.capo@ff.uns.ac.rs

** A tanulmány a Szerb Köztársaság Oktatási, Tudományügyi és Technológiai Fejlesztési Minisztériumának

178017-es számú projektuma keretében készült.
} 
bevonjuk az értelmezésbe (Faragó, 2011: 100-101), Hózsa Éva pedig arra figyel fel, hogy a regényt nagymértékben a szerző elmélyült komparatisztikai kutatásai szervezik (Hózsa, 2004). Dolgozatunkban Juhász Erzsébet esszéinek és tanulmányainak áttekintésével azt vizsgáljuk meg, hogy az irodalmi értelmezésekben és esszékben megfogalmazott felismerések hogyan épülnek be a Határregény epikai szerkezetébe.

\section{A Monarchia értékválsága}

A Tükörképek labirintusának bevezetőjében Juhász Erzsébet kijelöli, hogy kötetében olyan közép-európai müveket értelmez, ,amelyekben meghatározó az érvényben lévő értékek rendszerének megingása vagy felbomlása" (Juhász, 1997: 9). E müvek kritikával közelítenek ábrázolt világukhoz, még ha a múltat nosztalgikus fénybe is vonják.

Az értelmezés egyik kulcsfogalma a Habsburg-mítosz. A Claudio Magris által vizsgált jelenség, a Habsburg-mítosz kialakulása a 19. század elejére tehető, arra az időszakra, amikor a Birodalom elveszítette világpolitikai befolyását, a mítosz megerősödéséhez, irodalmi megnyilvánulásaihoz azonban az osztrákmagyar államalakulat szétesését követő válság vezetett. A Habsburg-mítosznak Magris szerint egy ellentmondás az alapjegye: benne a történelmi valóság és annak önkéntelen vagy szándékos átlényegítése ellentétbe áll egymással (Juhász, 1997: 21).

A cseh szociológus és filozófus, Bělohradsky úgy látja, a Monarchia a barokk kori állameszmével igazolta fönnállását a 19. században is, amikor az állami legalitás alapja az etnikai egység lett (Juhász, 1997: 103). A többnemzetiségü Habsburg Birodalomban a barokk kori legitimitást a legalitásnak sajátos válfaja váltotta fel. $\mathrm{Az}$ egyetemes eszme szerepét a Monarchiában az államgépezetben kifejeződő racionalitás, a szinte vallásos szentség rangjára emelkedő bürokrácia vette át (Juhász, 1997: 103). Annak pedig, hogy a történelmi-társadalmi valóságot egy fiktív, illuzórikus valósággal helyettesítették be, a burjánzó etikátlanság volt a kiváltó oka (Juhász, 1997: 14-15).

A Habsburg-mítosz müködését Juhász Erzsébet a Krúdy-regények segítségével mutatja be. Megfigyeli, hogy A vörös postakocsi föhőse, Alvinczi Eduárd „kétarcú”: lénye emelkedettebb felével minden évben színre viszi esküvőjét kitartott szeretőjével, Lottival, e némajátékban pedig „valamely letűnt időbe beleképzelt életforma fragmentuma elevenedik meg halálesztétikát és halálerotikát árasztva" (Juhász, 1997: 21). Alvinczi másik énje azonban vagyongyarapító szerencsejátékos. Kettős szubjektumának mitikus vonásait bizonyítja, hogy a 
szublimált szerepjáték költségeit az alantas vagyonszerző tevékenysége teremti elő (Juhász, 1997: 18). Az Öszi utazás a vörös postakocsin címü Krúdy-regény legföbb esztétikai értékét Juhász Erzsébet abban látja, hogy Krúdy elbeszélésében végig fenntartja a „kísértet-lét atmoszféráját”, miközben az elmondott utazás referenciálisan is lejátszódik. Alvinczire, aki Bécsből indul el, útja során csak az egykor ismert emberek és dolgok hasonmásai, pótlékai várnak, az is kiderül azonban, hogy a múltban sem lehetséges az eredeti azonosítása (Juhász, 1997: 28): „a letünt idő keresése az Öszi utazás a vörös postakocsin című regényben a kísérteties jelen idő megjelenítésének eszközé”-vé válik (Juhász, 1997: 34).

Könyvében Juhász Erzsébet a közép-európai irodalom körébe olyan kortárs mủveket is besorol, melyek jóval a Monarchia felbomlása után jöttek létre. Ezeket az alkotásokat, melyeket „nem a történelmi valóság és annak önkéntelen vagy szándékos átlényegítése szervez" (Juhász, 1998: 21), a világlátás hasonlósága kapcsolja a Monarchia irodalmához. Bělohradsky megállapítja, a mitteleurópai filozófia egységes jegye, hogy az élet és az állami racionalitás kiegyenlítésének szándékát abszurdnak érzi (Juhász, 1997: 110). Az ebből a belátásból következő „mitteleurópai groteszk” zárt világot feltételez. Ebben a világban nincs egyetlen müködőképes értékrendszer sem, „így a groteszk tagadni kényszerül minden abszolútumot és bárminemü értékrendszernek a puszta lehetőségét is.” (Juhász, 1997: 122). A totalitarizmus bármilyen változata kioltja a lelkiismeretet, az emberi közösséget értelemtől megfosztott gépezetté alakítja (Juhász, 1997: 119). Danilo Kiš Fövenyóra címü regényének az emberi közösségből a származása miatt kitaszított, a cselekvés minden lehetőségétől megfosztott főhőse számára utolsó lehetőségként a helyzetével való szembenézés marad. Abban a zárt, minden értéktől megfosztott világban azonban, amelybe került, a józan életlátás és őrület azonos egymással.

Juhász Erzsébet esszéiben és tanulmányaiban több helyütt idézi Danilo Kišnek a formáról megfogalmazott állításait, azt a mondatot is, mellyel Kiš a közép-európai kötődésủ írók közös tulajdonságaként a forma tudatát jelöli ki (Juhász, 1997: 134). A forma egyszerre könyörtelen látlelet és rend, „a barbár ziláltság és az ösztönök irracionális önkényének ellentéte" (Kišt saját fordításában idézi: Juhász, 1997: 134).

\section{Az írás mint meditáció}

1993-as esszékötete, az Esti följegyzések a balkáni háborúk idején keletkezett. Juhász Erzsébet központi szerepet juttat a kisebbségi helyzet és a kisebbségi irodalom kérdésének. A gyüjtemény első esszéjének tárgya Márai 
Sándor 1943-44-es, háborús naplója. Márai egyik bejegyzésében a háború helyzetében előállt írásképtelenségét azzal magyarázza, hogy „egy író egyszerüen idegrost egy szellemi organizmusban, $\mathrm{s}$ ha az organizmus egészét hüdés éri, ha az idegrost nem kapja meg a szellemi szervezet egészétől a szükséges vérellátást, megszünik létezni” (idézi Juhász, 1993: 7). Az esszé záradékában Juhász Erzsébet felveti, a kisebbségi „szellemi szervezet” megkülönböztető jegye az, hogy „eleve hűdéses" (Juhász, 1993: 9). Esszék sorozatában utasítja el, hogy a nemzetiségi írónak az a feladata, hogy a kisebbségi sors kérdéseit közérthető módon megfogalmazza: az író, bárhol él is, „a létezésszakmában” dolgozik. Az eleve hátrányokkal teli kisebbségi létforma saját tapasztalatát kizárólag olyan irodalmi művek közvetíthetik hitelesen, melyeknek megkülönböztető vonásuk a forma tudata.

Mükedvelők címü, 1985-ben megjelent regényében, ,a vajdasági irodalmi identitás kiépítésének kulcsregényé"-ben (Bencsik, 2013: 107) Sztantits Aurél néven Szenteleky Kornélt, a vajdasági magyar irodalom első világháború utáni organizátorát tette meg főhősnek. A regényben Szenteleky mindvégig mint „nagyapánk” szerepel. Esterházy Péter - a hivatalos irodalom hagyományától eltérő hagyományra való jogot hangsúlyozva - Kosztolányit egyik esszéjében bátyánknak nevezte (Esterházy, 1988: 45). Szenteleky, aki a helyi színek programjának meghirdetésével „elsősorban íróink magatartásán szeretett volna változtatni” (Utasi Csaba, 1984: 18), nem az elbeszélői eljárások tekintetében „,rokonunk”. Az általa meghirdetett programot Juhász Erzsébet nem kívánja „értékjelképpé” vagy „létszimbólummá” (Juhász, 1996a: 92) tenni. Szenteleky sorsának és törekvéseinek megidézésével a kisebbségi helyzet mindenkori jegyeit rajzolja meg. Az elbeszélő a főhős számvetését közvetítő szólamában a hiányok domborodnak ki:

De vajon megadatott-e egyáltalán neki és nekik valamennyiüknek ott, az Ákácok alatt a jelen időbe ténylegesen bekapcsolódva élniük? Hiszen az az idő, amelyikbe beleszülettek egykor, mint akik fölöslegesek, rég kivetette magából öket. Ahhoz, hogy egy másik megélhető idő képződjék körülöttük, a jövő időt kellett meg - vagy inkább kitalálniuk, ami felé haladhatnának. Éveken át csak a saját múltjukban érezhették otthon magukat. Így lettek - anélkül, hogy helyükröl egy tapodtat is elmozdultak volna - emigránsok. (Juhász, 1985: 107)

A délszláv polgárháború ,tőszomszédságában, riadt és kétségbeesett szemtanújaként a vérontásba torkolló gyülöletnek, a teljes erkölcsi és gazdasági csőd kellős közepén, jobb idők eljövetelének szikrányi reális esélye, szívbeli reménysége híján" (Juhász, 1993: 5), Juhász Erzsébet elsősorban arra keres választ, hogy a mindentől megfosztó, szorongató hiány állapotában hogyan lehetséges 
számára a „konkrét tér- és időkoordinátái közül való kiszabadulás átmeneti élményét” jelentő írás és elmélyült olvasás.

Bencsik Orsolya finom megfigyelése, hogy noha Juhász Erzsébet könyve nem feleltethető meg maradéktalanul a hüpomnémata ókori fogalmának - amely számadási könyv, közügyekről való beszámoló, emlékeztetőül szolgáló feljegyzés-, könyve mégis e müfajba sorolható azon az alapon, hogy olvasott idézetekből, az ezekre adott reflexiókból és személyes élményekből épül fel (Bencsik, 2016: 82).

A hüpomnémata müfajának meghatározó jegye, hogy „az epiktétoszi értelemben felfogott írás mint meditáció, mint az önmagára irányuló gondolkodásbeli gyakorlat” (Bencsik, 2016: 81) a már tudottat eleveníti fel és arra reflektál. Bencsik Orsolya szerint, „ha elfogadjuk Foucault értelmezését, a hüpomnémata a jövő bizonytalanságából, a jelenbe vetett szorongásból a múlt felé [...] mozdítja ki a szubjektumot." (Bencsik, 2016: 85). Az ókori példákban, melyeket Foucault elemez, a múlt, amely felé a napi írásgyakorlat kimozdítja a szubjektumot, az irodalmi hagyománnyal egyenlő. Az egyén a múltbeli diskurzus segítségével nyilváníthatta meg mások számára láthatóan, értékelhetően önmagát. A romantikától, az autonóm irodalom kialakulásának fogva megnő az egyéni tapasztalat értéke, a múlt ettől kezdve válik a személyes emlékek, benyomások tárházává.

Az esszékötet elbeszélője olvasmányaiból, a halottak napjához, a télhez, az adventhez, a karácsonyhoz kapcsolódó emlékekből, képzettársításokból kiindulva jut el az irodalmi kifejezés kérdéséig. Megjegyzi például, hogy a jelen szorongató sötétsége elől a gyerekkori érzékelés tágasságához kellene visszatérni. Később az önmagunkról való megfeledkezésnek azt a válfaját idézi fel, mely az idő múlásával következik be:

Egyre kevésbé vagyunk önmagunkban hangsúlyosak, nem a tulajdon kirajzolódásunk, megneveződésünk foglal el bennünket többé, hanem 'birtokunk', mellyel körülkerítettük magunkat. Véletlenül se kertes házra gondoljon senki. Hanem mindenekelött benső életterünkre és életvitelünkre: kötődéseinkre, ezekre a hajszálgyökerekre, melyeken keresztül belekapcsolódunk a bennünket körülvevő világ áramába (Juhász, 1993: 72).

A karácsony jelentőségének taglalása észrevétlenül ennek a fent említett, az idő múlásával létesülő benső élettérnek a feltételeire világít rá: „Kölcsönösség nélkül nem lehetséges bensőségesség. A bensőségesség a szeretet interakciója, egymás közötti cseréjének árama. A bensőségesség mélységes áhítása és hívása az ima“ (Juhász, 1993: 85). Pilinszkyt idézi tanúságul, aki szerint az imádság: 
„Egyfajta metanyelv, némaságában is egyféle beszélgetés mindennel és mindenkivel" (Juhász, 1993:86).

A szorongató jelenből egyedül az irodalom élménye szabadíthat ki:

[...] csak a müvészet képes életben tartani az élet érzékelésének gyerekkori spontán tágasságát [...] Látom magam elött a vörös postakocsi mögé fogott szánokat, ahogy keresztül-kasul szeldesik a felvidéki erdőségeket. A világ körös-körül a valószerütlenségig kifehérült. $\mathrm{S}$ ebben a már-már egyetemes télben és hófehérségben a Krúdy-hősök lelke is annyira kitágult, hogy túllendülhet a személyesség egyszeriségén és fölcserélhetetlenségén. Kezdetét veszi a havas lélekben a mese, minden lehetségessé lesz: életre kelnek a holtak, magukra találnak a lelkek (Juhász, 1993: 77-78).

A világ, a jelenségek és önmagunk „birtokbavétel”-nek fönti formája állandó reflexiót feltételez, a kialakult értékhiánnyal, a determinációkkal való folyamatos szembenézést. A megfogalmazódó reményt a tisztánlátás teszi megrendítővé.

\section{Írói eljárások}

A Határregény egy térségbeli család több generációjának életútját, kapcsolatait mutatja be. A regényben világosan kibontakozik az a szándék, amely a Monarchia széthullásától a balkáni háborúkig mutatja be azt, hogy az államalakzatok módosulása az emberi identitásban milyen rombolást visz végbe. Bence Erika értelmezése középpontjába ezt a mozzanatot állította:

A kényszerü határok közé szorult, magukat fogolyként meghatározó személyek, illetve a beszorítottság képzetkörében felnőtt utódaik sorra létrehozzák belső határmezsgyéiket is, amelyek elsősorban társadalmi kapcsolataikban, családon belüli viszonyaikban jelentenek áthatolhatatlan falat (Bence 2008, 118-119).

Azt is mondhatnánk azonban, hogy a regénynek azok a hösei, akik kulturális identitásukat a Monarchiában alakították ki, az államalakzat szétesése után - etnikumuktól függetlenül - kisebbségi helyzetbe kerülnek. A nagyapák nemzedékéhez tartozó, a Monarchia széthullása után Szabadkán élő Patarcsics Miklós „már nem volt se bunyevác, se horvát, se szlovén, de még nem volt igazán magyar sem [...], úgy érezte, ha egyetlenegyszer igazából át tudná érezni, hogy ő magyar, az maga lenne a révbe jutás" (Juhász, 2001: 61). A Nagyváradon született, zaklatott idegzetü Sajtos Lina a trianoni határmódosulást követően idegenül érzi magát szülővárosában, végül azonban rádöbben: „ő maga nem is a reménytelen szerelmek, a mindent végérvényesen szétziláló világháború, nem is egy 
visszataszítóvá lett ország foglya, hanem a tulajdon sorsáé, s mindez annyira önmagán belül van, hogy soha, míg él, nem lehet belőle szabadulása." (Juhász, 2001: 76). A hiány válik személyisége alapjává. Halála előtt utolsó erejével dörömbölni próbál az ajtón, miközben zokogva azt kiabálja:,Engedjetek be!”.

A nagyepikai kompozíciónak valószínúleg Emi nézőpontja lett volna a(z egyik) fókusza. A regény a múltat a a balkáni háború jelenéből rekostruálja. Az unokák generációja, akik közé Emi is tartozik, a testvériség-egység Nagyjugoszláviát szervező eszméjével nem azonosult maradéktalanul, ám Magyarországot sem érezte hazájának:

A hatvanas évek elején volt elöször Magyarországon. Anyanyelvélményként valósággá vált, minden más téren idegen, valószerütlen maradt. Éppúgy nem volt köze a HAZÁNK-hoz, mint annak az országnak, amelybe beleszületett, s végül úgy széthullott, hogy máig is bizonytalan, hol vannak a határai, s meddig lesznek ott, ahol vannak. (Juhász, 2001:16)

Az Esti följegyzésekben is vázolt két magatartás, az elmélyült olvasás és az írás a regényben Emi és bátyja, Emil között oszlik meg. A testvérek közül Emiből hiányzott az alkotóerő, kreativitása az értő olvasásra szorítkozott, Emil volt kettőjük közül az író (az Emilt középpontba állító fejezet azonban nem készült el).

A szereplők némelyike csupán az álmok és a rögeszmék nyelvén tudja kommunikálni tapasztalatát, nekik az elbeszélés szolgáltat igazságot. Mások a lehetőségeik teljes lezárulta után bekövetkező tisztánlátás szabadságáig érkeznek el.

A Vajdaság Szerb Köztársaságon belüli autonómiájának megnyirbálásához vezető 1988-as, ún. joghurtforradalmat követően Emi zeneszerző férje, Boro az emigrációt választja, Emi pedig az elköltözés és az otthonmaradás esélye között őrlődve akkor jut el végre a megnyugvást hozó felismeréshez, amikor férje konkrét zenei kompozícióját hallgatja. Az grožnjani nyaralásuk egy bizonyos napján rögzített hangeffektusok emlékképeket idéznek fel benne, s a tenger utolsóként megképződő látványa váratlanul a „mindenre való nyitottság” állapotába helyezi ôt vissza, miközben világosan érzi: „hiába menekülne bárhova is, neki az a sorsa, hogy itt, a szülőföldjén élje meg mindazt, ami ráméretett” Juhász, 2001: 18). Boro másik szerzeménye távoli rokonuk, a nagyszülők generációjához tartozó Angeline Nenadovits halálának napján készült, miközben kint az utcán éppen zajlott a joghurtforradalom. Az ütemesen skandált Slobo-slobodo jelszó felidézi Emiben a tömeget, melynek zajongásába a zenei szerzeményben váratlanul bekapcsolódik a Bécsi vér néhány kibicsaklott üteme. A keringő taktusai egyszerre jelenítik meg a Bécsben született Angelinét és a Habsburg mítoszt. Juhász Erzsébet a mítosz pólusai közül csupán az egyiket, az értékhiányt képezi meg szövegében, a látszattá 
és dekórummá ,átlényegített történelmi valóság”-ot mindössze metaforaként, idézetként illeszti regényébe.

\section{Csilla Utasi, Ispánovics Csapó Julianna}

\section{SELF-REFLECTION AND RECKOGNITION IN THE PROSE OF ERZSÉBET JUHÁSZ}

\section{Summary}

Erzsébet Juhász has always created situations in her epic works which established her protagonists' issues regarding identity. In her collection of short stories Gyöngyhalászok [Pearlers], it is the family that represents the social environment influencing identity on a fundamental level, and in her novel Mükedvelök [Art Lovers], she presents the cultural conditions defining minority existence in the period between the two world wars. Her final, posthumously published novel Határregény [Frontier Novel], which remained in fragments, is set in parallel time periods: the present of the Balkan Wars and in the period following the dissolution of the Austro-Hungarian Monarchy. The structure, indicative a great epic composition, was formed by the editors based on the completed fragments; however, even these make the author's intent of a parallel between the dissolution of the Austro-Hungarian Monarchy and the distintigration of Yugoslavia palpable. Juhász's 1993 collection of essays and 1997 collection of studies can, in a sense, be considered the predecessors of Határregény [Fontier Novel]. In her essays, she examines the situation ensuing after the Balkan Wars, the state of existence as a national minority, the question of CentralEuropeanness, and the chances of hope from the perspective of a creator. She discovers hope only in a dimension beyond the reach of everyday existence-reading and writing. Her studies on the literature of the Monarchy bear witness to these life experiences as well. This paper examines how the revelations described in the collections of essays and studies by Erzsébet Juhász are represented in the epic text of the Határregény [Frontier Novel].

Keywords: identity issues, Balkan Wars, Central Europe, minority existence, experience.

Čila Utaši, Išpanović Čapo Julijana

\section{AUTOREFLEKSIJA I SPOZNAJA U PROZI ERŽEBET JUHAS}

\section{Rezime}

Eržebet Juhas je u svojim proznim delima od početka stvarala situacije u kojima su artikulisana pitanja vezana za identitet njenih junaka. U zbirci pripovedaka pod naslovom Gyöngyhalászok [Sakupljači bisera] porodica predstavlja ono društveno-socijalno okruženje koje na elementaran način određuje identitet, a u njenom romanu pod naslovom Mükedvelök [Diletanti] opisuje kulturne prilike koje su između dva svetska rata određivale život manjina. Radnja njenog posthumno objavljenog romana Határregény [Roman o granici] paralelno se 
odvija u sadašnjosti balkanskih ratova i u periodu posle raspada Austro-Ugarske. Uređivači su bili ti, koji su od fragmenata iz zaostavštine stvorili jednu takvu strukturu romana, iz koje se naslućuje velika epska kompozicija, međutim i u samom tekstu se jasno uočava autorska intencija da se raspad Austrogarske carevine posmatra paralelno sa raspadom Velike Jugoslavije. Eseji Eržebet Juhas koji su objavljeni 1993. godine. (Esti följegyzések [Večernji zapisi]), kao i njena zbirka iz godine 1997. (Tükörképek labirintusa [Lavirint odraza u ogledalu]) mogu se u izvesnom smislu shvatiti kao pripreme za Határregény [Roman o granici]. U svojim esejima Eržebet Juhas analizira situaciju koja je nastala izbijanjem balkanskih ratova, istražuje mogućnost nade, život u manjinskim prilikama, pitanje pripadanja Srednjoj Evropi iz perspektive čoveka stvaraoca. Nadu pronalazi u doživljaju čitanja i pisanja, u dimenziji koja svakodni život stavlja van snage. O ovom ubeđenju svedoče i njene studije u kojima interpretira književnost Dvojne monarhije. U radu se istražuje način na koji se iskustvo i spoznaja koji se ispoljavaju u njenim esejima $\mathrm{i}$ studijama upisuju u prozno tkanje romana Határregény [Roman o granici].

Ključne reči: pitanja identiteta, balkanski ratovi, Srednja Evropa, manjinski život, iskustvo.

\section{FORRÁSOK}

Juhász, E. (1985). Mükedvelők. Újvidék: Forum.

Juhász, E. (1993). Esti följegyzések: Egy évad a balkáni pokolból. Újvidék: Jugoszláviai Magyar Müvelődési Társaság.

Juhász, E. (1996). Tükörképek labirintusa: Tanulmányok a közép-európai irodalmak köréböl. Újvidék: Forum.

Juhász, E (2001). Határregény. Újvidék: Forum.

\section{IRODALOM}

Bence, E. (2008). Határtörténetek a jelenkori vajdasági magyar irodalomban, Hungarológiai Közlemények 1, 116-124.

Bencsik, O. (2013). A halál és a vidék találkozása két mükedvelőben: Juhász Erzsébet portalanítja Szenteleky Kornélt. Forrás 2, 105-112.

Bencsik, O.(2016 ). A hüpomnémata-írásban lakozó Juhász Erzsébet. Hid, szeptember, 81-87.

Esterházy P. (1988). Ünnepi beszéd és rekonstrukció, In: Esterházy, P. Kitömött hattyú (43-53). Budapest: Magvetö.

Faragó, K. (2001). Utószó: Közép-Európai határjáték. In: Juhász Erzsébet: Határregény (95-101). Újvidék: Forum. 
Hózsa, É. (2004). Két határregény. In. Hózsa, É. Idevonzott irodalom. Szabadka, Grafoprodukt. zEetna 2010. http://www.zetna.org/zek/konyvek/116/ hozsa09.html (letöltve 2018. augusztus 27.)

Juhász, E. (1996a). Az ugartörés mint önmetafora. Tiszatáj, 1. 92-98.

Utasi, Csaba (1984). Irodalmunk és a Kalangya.Újvidék: Forum 
МЕДИЈСКЕ СТУДИЈЕ 
